\title{
Distribution and habitats of Burnupia trapezoidea (Boettger, 1910) (Gastropoda: Ancylidae) in South Africa
}

\author{
KN de Kock ${ }^{1 *}$ and CT Wolmarans ${ }^{1}$ \\ ${ }^{1}$ Unit for Environmental Sciences and Management, Potchefstroom Campus of the North-West University, Private Bag X6001, Potchefstroom 2520, \\ South Africa
}

\begin{abstract}
This paper deals with the geographical distribution and habitat preferences of B. trapezoidea, the third most widespread species of the 14 species of Burnupia currently on record in the database of the National Freshwater Snail Collection (NFSC) of South Africa. Although the 121 loci ( ${ }^{1} / 16$ square degrees) from which the 445 samples of B. trapezoidea were collected are much fewer than the number reported for $B$. capensis, the range of its geographical distribution is almost as widespread as that of B. capensis. The limited distribution of B. trapezoidea in the Limpopo, Northern Cape and Western Cape Provinces can most probably be attributed to the paucity of perennial water bodies in these areas and the fact that Burnupia spp. in general have poor abilities to overcome conditions of desiccation prevalent in these areas. It is therefore not surprising that the majority of samples were collected in perennial rivers and streams. A Random Forest statistical analysis selected water bodies, the presence or absence of marginal and aquatic vegetation, and type of substratum as the most important variables that played a significant role in determining the presence and numbers of specimens of $B$. trapezoidea in a specific area. In this respect, temperature and turbidity, respectively, played a moderate and minor role. Little is known regarding the conservation status of Burnupia spp, in general, but habitat degradation and climatic warming could be reasons for concern. However, in extensive on-going biodiversity surveys in two rivers and selected tributaries in the North-West Province, many new distribution records of $B$. trapezoidea are still being created and therefore this species could probably be considered for listing as not endangered. In view of its wide distribution, largely sessile, benthic lifestyle, and ability to bioaccumulate various substances, the feasibility to utilise it as indicator of river ecosystem health in South Africa should be explored.
\end{abstract}

Keywords: Mollusca, Ancylidae, Burnupia trapezoidea, geographical distribution, habitat preferences, conservation status, South Africa

\section{INTRODUCTION}

The first comprehensive study of the Ancylidae in South Africa was published by Walker (1923), but the presence of this family in this country was already reported many years earlier (Krauss, 1848). Another important contribution regarding knowledge of this family was made in a monographic survey of the South African non-marine Mollusca (Connolly, 1939). These contributions focused mainly on taxonomic characteristics of the Ancylidae and little information pertaining to the habitat preferences and range of their geographical distribution was made available. Up till the present, 14 species of Burnupia have been reported from southern Africa (Brown, 1994; Appleton 2002; Griffiths et al., 2015). However, Brown (1994) mentions the need for investigating the genetic basis of variation among populations and taxa to understand speciation within the Ancylidae. This view is supported by Appleton (2002), who is of the opinion that revision of this family is needed at both generic and species level.

Of all the species of Burnupia currently on record in the database of the National Freshwater Snail Collection (NFSC), a comprehensive account of the distribution and habitat preferences of only two of the most widespread Burnupia species in South Africa, namely B. capensis and B. stenochorias, has yet been published (De Kock and Wolmarans, 2009). The current paper deals with the geographical distribution and habitat

*To whom all correspondence should be addressed

Tel. 018299 2380; e-mail: kenne.dekock@nwu.ac.za

Received 14 June 2016; accepted in revised form 20 March 2017 preferences of B. trapezoidea, the third most widespread species of this genus in South Africa, as reflected by the records in the database of the NFSC.

\section{MATERIALS AND METHODS}

Burnupia species are relatively inconspicuous freshwater limpets. They are usually attached to solid objects on the substratum or marginal and aquatic vegetation in a wide variety of water body types. However, they need to be specifically looked for during surveys. Up until the late 1980s, Health personnel of government institutions and municipalities made substantial contributions to the number of samples in the NFSC. These personnel received special training regarding sampling techniques during workshops organised by staff of the former Snail Research Unit at the Potchefstroom University for Christian Higher Education. All persons involved in these surveys were provided with a printed collector's form compiled by staff of the former Snail Research Unit. The locality of the collection had to be entered and various alternatives regarding the type and conditions of the habitat had to be underlined, according to the judgment of the collector at time of collection. From1990 up until the present, additions to the NFSC have come mainly from collections made during a number of surveys conducted by scientists and students from the Potchefstroom Campus of the North-West University, where the NFSC is housed.

Identification of the specimens was done by following the diagnostic criteria laid down by Walker (1923), Connolly (1939) and Oberholzer and van Eeden (1969), and was based largely on shell and radula characteristics; however, origin of the samples was also taken into account. Details of the biotopes of all samples 
of B. trapezoidea, dating from 1956 to 2016, which could be located on a 1:250 000 topo-cadastral map series of South Africa, were extracted for analysis from the NFSC database.

The 121 loci $\left({ }^{1} / 16\right.$ square degrees $)$ in which the collection sites were located were distributed in preselected intervals of mean annual air temperature and rainfall to illustrate the frequency of occurrence of this species within specific intervals. Statistica 12, Nonparametrics, 2 x 2 Tables, McNemar Fischer exact software were used to calculate Chi square values to determine the significance in difference between the frequency of occurrence in, on, or at the range of options for each variable, such as type of water body, type of substratum or temperature interval. An effect size (Cohen, 1977) was calculated for all the different variables discussed in this paper. The effect size is an index which measures the degree of discrepancy between the frequency distribution of a given species in the set of alternatives of a given variable such as water bodies, as compared to the frequency of distribution of all other mollusc species in the database in the set of alternatives for the same variable (Cohen, 1977). According to this author, values for this index in the order of 0.1 and 0.3 indicate small to moderate effects respectively, while values in the order of 0.5 and higher indicate practically significant large effects. A more detailed account of the significance and interpretation of specific values calculated for this index in a given situation is given in our earlier publications (De Kock and Wolmarans, 2005a; b).To determine the importance of the role played by each of the variables recorded in the database on the occurrence, numbers and geographical distribution of $B$. trapezoidea, a Random Forest analysis (Liaw and Wiener, 2002; $\mathrm{R}$ Core Team, 2013) was done. The mean decrease in accuracy caused by a variable is determined during the out of bag error calculation phase. The more the accuracy of the Random Forest decreases due to the exclusion (or permutation) of a single variable, the more important that variable is deemed and therefore variables with a large mean decrease in accuracy are more important for classification of the data.

\section{RESULTS}

The 445 samples of $B$. trapezoidea which could be pinpointed on a topo-cadastral map series fell within the 121 loci depicted in Fig. 1.

This species was collected in 10 of the 14 different waterbody types represented in the database. The largest numbers of samples came from rivers and streams; however, the six samples collected in springs represented a slightly higher percentage $(1.74 \%)$ of the total number of times molluscs were reported from this type of water body in the database (Table 1).

The frequency of occurrence in rivers and streams did not differ significantly $(\chi=1.46, d f=1 ; p>0.05)$; however, Chi square values indicated that the frequency of occurrence in

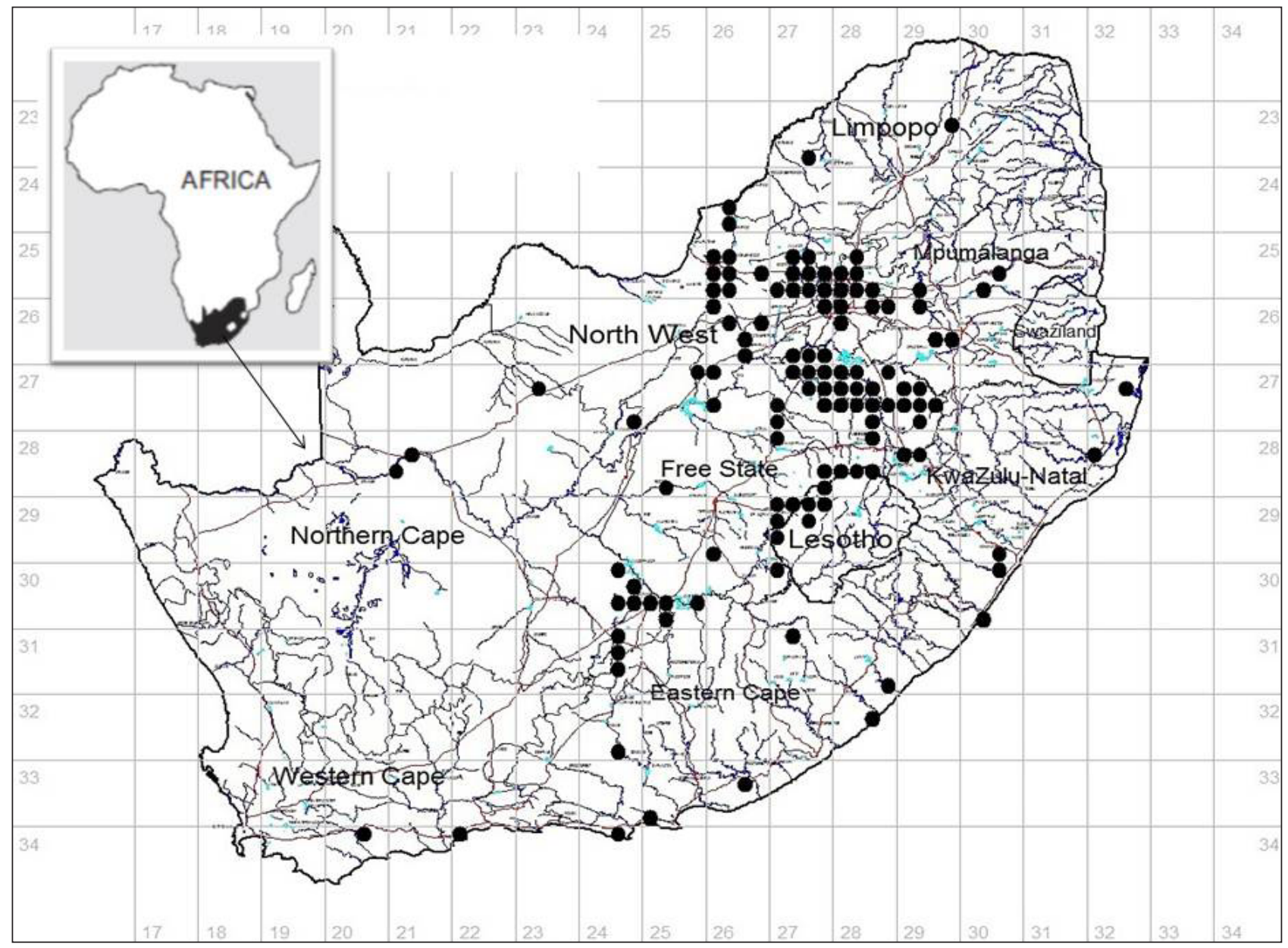

Figure 1

Geographical distribution of Burnupia trapezoidea in 1/16 square degree loci in South Africaas reflected by the 445 records in the database of the National Freshwater Snail Collection 
these two water body types differed significantly $(p<0.05)$ from most of the other types of water body. An effect size of 0.44 , which is deemed as moderate to large, was calculated for water bodies. The majority of samples were collected in perennial habitats for which the water conditions were described as clear and fresh, while equal numbers of samples were reported from slow-running and standing water (Table 2). The frequency of occurrence in perennial water did not differ significantly from seasonal water $(\chi=0.83, d f=1 ; p>0.05)$. A large value was calculated for the effect of current speed, while both perennial and seasonal water, as well as turbidity, had only a small effect and salinity no effect at all (Table 2).

The majority of samples were reported from water bodies with predominantly stony substrata (Table 3 ) and the frequency of occurrence on this type of substratum differed significantly ( $p$ $<0.05)$ from all other types.

More than $80 \%$ of the samples were collected at sites which fell within the interval of mean annual temperature ranging from

\section{TABLE 1}

Types of water bodies in which Burnupia trapezoidea was found in $\mathbf{4 4 5}$ collection sites recorded during surveys

\begin{tabular}{|l|c|c|c|c|}
\hline Water bodies & A & B & C & D \\
\hline Channel & 1 & $0.22 \%$ & 182 & $0.55 \%$ \\
\hline Dam & 74 & $16.63 \%$ & 8452 & $0.88 \%$ \\
\hline Ditch & 1 & $0.22 \%$ & 642 & $0.16 \%$ \\
\hline Pool & 1 & $0.22 \%$ & 233 & $0.45 \%$ \\
\hline Pond & 5 & $1.12 \%$ & 1632 & $0.31 \%$ \\
\hline Quarry & 1 & $0.22 \%$ & 126 & $0.79 \%$ \\
\hline River & 131 & $29.44 \%$ & 7617 & $1.72 \%$ \\
\hline Spring & 6 & $1.35 \%$ & 345 & $1.74 \%$ \\
\hline Stream & 124 & $27.87 \%$ & 7410 & $1.67 \%$ \\
\hline Swamp & 7 & $1.57 \%$ & 2080 & $0.03 \%$ \\
\hline
\end{tabular}

Effect size: $w=0.44$ (moderate to large effect)

A: Number of times collected in a specific water body

$B: \%$ of the total number of collections on record for this species

C: Number of times any mollusc was collected in a specific water body

$D: \%$ occurrence of this species in the total number of collections in a specific water body
16 to $20^{\circ} \mathrm{C}$ (Table 4 ) and the frequency of occurrence differed significantly from sites falling within the other two intervals in which samples were collected $(p>0.05)$. More than $70 \%$ of the samples were reported from sites falling within the interval of mean annual rainfall ranging from 601 to $900 \mathrm{~mm}$ (Table 4). A moderate and a moderate to large effect value were calculated for rainfall and temperature, respectively (Table 4).

The Random Forest analysis (Fig. 2) selected water bodies, the presence or absence of marginal and aquatic vegetation, and type of substratum as the most important variables that played a significant role in determining the presence and numbers of specimens of B. trapezoidea in a specific area. In contrast, according to this analysis, temperature had a moderate effect, while current speed and turbidity played only a minor role in this respect.

\section{DISCUSSION}

Burnupia trapezoidea was described by Boettger in 1910 from the type locality in Botswana (Brown, 1994), and its occurrence in South Africa was reported 2 years later by Walker (1923).

\begin{tabular}{|c|c|c|c|c|}
\hline & tratum typ & $\begin{array}{r}\text { TAB } \\
\text { he habit } \\
\text { cribed d }\end{array}$ & $\begin{array}{l}\text { f Burnup } \\
\text { surveys }\end{array}$ & trapezoidea as \\
\hline & & Subst & n types & \\
\hline & Muddy & Stony & Sandy & $\begin{array}{c}\text { Decomposing } \\
\text { material }\end{array}$ \\
\hline A & 114 & 200 & 62 & 9 \\
\hline B & $25.62 \%$ & $44.94 \%$ & $13.93 \%$ & $2.02 \%$ \\
\hline $\mathrm{C}$ & 12907 & 8008 & 6880 & 652 \\
\hline D & $0.88 \%$ & $2.50 \%$ & $0.90 \%$ & $1.38 \%$ \\
\hline E & $w=0.53$ & fect) & & \\
\hline
\end{tabular}

A: Number of times collected in a water body with a specific substratum $B: \%$ of the total number of collections (445) on record for this species $C$ : Number of times any mollusc was collected in a Water body with a specific substratum

D: \% occurrence of this species in the total number of collections in a water body with a specific substratum

E: Effect size values calculated for substratum types

\begin{tabular}{|l|c|c|c|c|c|c|c|c|c|}
\hline \multicolumn{8}{|c|}{ TABLE 2 } \\
\hline & \multicolumn{2}{|c|}{ Type } & \multicolumn{3}{c|}{ Current speed } & \multicolumn{2}{c|}{ Turbidity } & \multicolumn{2}{c|}{ Salinity } \\
\hline & Perennial & Seasonal & Fast & Slow & Standing & Clear & Muddy & Fresh & Brackish \\
\hline A & 259 & 70 & 33 & 148 & 148 & 262 & 87 & 267 & 8 \\
\hline B & $58.20 \%$ & $15.73 \%$ & $7.42 \%$ & $33.23 \%$ & $33.23 \%$ & $58.88 \%$ & $19.55 \%$ & $60.00 \%$ & $1.80 \%$ \\
\hline C & 22807 & 5386 & 2308 & 9903 & 16192 & 20334 & 6669 & 24446 & 697 \\
\hline D & $1.27 \%$ & $1.30 \%$ & $1.43 \%$ & $1.49 \%$ & $0.91 \%$ & $1.29 \%$ & $1.30 \%$ & $1.09 \%$ & $1.15 \%$ \\
\hline E & $w=0.20$ (small effect) & $w=0.83$ (large effect) & & $w=0.01$ (small effect) & $w=0.0$ (no effect) \\
\hline
\end{tabular}

A: Number of times collected in a specific water condition

$B: \%$ of the total number of collections (445) on record for this species

$C$ : Number of times any mollusc was collected in a specific water condition

D: \% occurrence of this species in the total number of collections in a specific water condition

E: Effect size values calculated for each factor 
TABLE 4

Frequency distribution of the $\mathbf{4 4 5}$ collection sites of Burnupia trapezoidea in selected intervals of mean annual air temperature and rainfall in South Africa

\begin{tabular}{|l|c|c|c|c|c|c|c|}
\hline & \multicolumn{3}{|c|}{${\text { Temperature intervals }\left({ }^{\circ} \mathbf{C}\right)}^{-}$Rainfall intervals (mm) } \\
\hline & $\mathbf{1 1 - 1 5}$ & $\mathbf{1 6 - 2 0}$ & $\mathbf{2 1 - 2 5}$ & $\mathbf{0 - 3 0 0}$ & $\mathbf{3 0 1 - 6 0 0}$ & $\mathbf{6 0 1 - 9 0 0}$ & $\mathbf{9 0 1 - 1 2 0 0}$ \\
\hline A & 69 & 359 & 17 & 7 & 117 & 318 & 3 \\
\hline B & $15.51 \%$ & $80.67 \%$ & $3.82 \%$ & $1.57 \%$ & $26.29 \%$ & $71.46 \%$ & $0.67 \%$ \\
\hline C & 4467 & 24607 & 4783 & 1031 & 12734 & 19227 & 1236 \\
\hline D & $1.54 \%$ & $1.46 \%$ & $0.36 \%$ & $0.68 \%$ & $0.92 \%$ & $1.65 \%$ & $0.24 \%$ \\
\hline E & $w=0.40$ (moderate effect) & & $w=0.32$ (moderate effect) & & \\
\hline
\end{tabular}

A: Number of times collected in a locality falling within a specific interval

$B: \%$ of the total number of collections on record for this species

C: Number of times any mollusc was collected in a locality falling within a specific interval

D: \% occurrence of this species in the total number of collections within a specific interval

E: effect size values calculated for each factor

However, the oldest record of this species in the database of the NFSC was collected in 1957 in a stream on the farm Feeshuis 484 in the Soutpansberg district of the Limpopo Province, South Africa. Although the 121 loci from which the samples of $B$. trapezoidea were collected are much fewer than the 257 loci reported for B. capensis (De Kock and Wolmarans, 2009), the range of its geographical distribution (Fig. 1) almost as widespread as that of $B$. capensis. The poor distribution of $B$. trapezoidea in the Limpopo, Northern Cape and Western Cape Provinces can most probably be attributed to the paucity of perennial water bodies in these areas and the fact that Burnupia spp. in general have poor abilities to overcome conditions of desiccation prevalent in these types of water body (Brown, 1994). Brown (1994) records this species from Kamanyab in Namibia and Ngamiland in Botswana and is of the opinion that it probably occupies much of the range known for this genus, which is in accordance with the considerable overlap of its distribution with those of B. capensis and B. stenochorias reported by De Kock and Wolmarans (1909). Brown (1994) also mentions that $B$. trapezoidea is 'widely thought to occur only in Africa, but reports of its presence in the southern part of South America cast doubt on this.'

The large and moderate to large effect values which were calculated for types of water bodies and types of substrata, respectively, suggest that these variables played a significant role in establishing the documented geographical distribution of this species in South Africa, a conclusion also substantiated by the results of the Random Forest analysis (Fig. 2). These findings are also in accordance with the results reported for B. capensis and B. stenochorias by De Kock and Wolmarans (2009). The results of the Random Forest analysis also indicated that temperature and turbidity played a minor role in determining the presence or absence of $B$. trapezoidea in specific areas, findings also supported by the moderate to small effect values calculated for these two variables, respectively (Tables 2 and 4). Statistical analyses indicated that temperature only played a moderate role in the presence or absence of this species in a specific area, which is in accordance with its geographical distribution which shows that it was collected in aquatic biotopes located in some of both the coldest and warmest areas in South Africa (Fig. 1).

The findings that the majority of samples of $B$. trapezoidea were collected in rivers and in biotopes with stony substrata is in accordance with the results of a project currently in progress to assess the ecological health of the Marico River (North

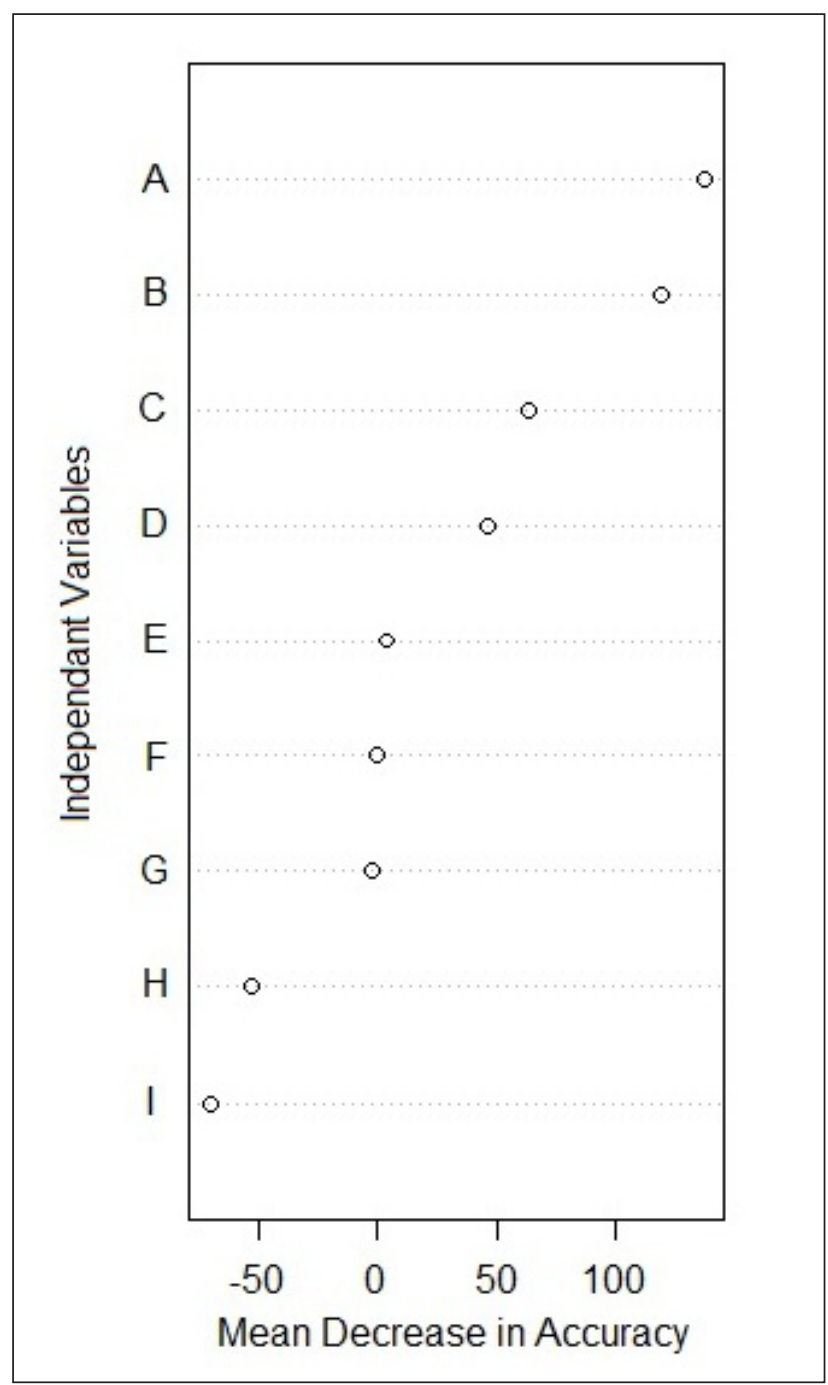

Figure 2

Results of the Random Forest analysis of the independent variables calculated for the 445 collection sites of B. trapezoidea. A: Water bodies; $B$ : Presence or absence of aquatic vegetation; $C$ : Types of substrata; $D$ : Perennial or seasonal water; E: Mean yearly air temperature per locus; $F$ : Brackish or fresh water; $\mathrm{G}$ : Mean yearly rainfall per locus; $\mathrm{H}$ : Current speed; I: Turbidity 
West Province) and the Crocodile River (North West and Limpopo Provinces), which is being conducted by the authors and postgraduate students of the Potchefstroom Campus of the North-West University (Kemp et al., 2016). During these surveys, many specimens of this species were found on stones in in-current and out-of-current biotopes. However, specimens were also found in aquatic and marginal vegetation biotopes, which also substantiate the results depicted in Fig. 2.

The importance of biotope availability for macroinvertebrate communities in South African rivers has already been reported by Dallas (2007) and Odume et al. (2015). The finding that $B$. trapezoidea can utilise benthic, as well as vegetation biotopes and is widely distributed in South Africa, makes it an excellent candidate for the assessment of the bioavailability of metals in river systems in South Africa. It is known that freshwater molluscs can accumulate metals in their soft tissue and also incorporate various mineral and organic substances in their shells (Carrell et al., 1987; Pourang, 1996; Korniushin, 2000). Laboratory experiments also indicated that B. stenochorias could possibly be exploited as an ecotoxicological indicator in wholeeffluent toxicity testing (Davies-Coleman and Palmer, 2004).

According to Lydeard et al. (2004) the largest number of documented extinctions, out of all taxa, are reported for the molluscs. Furthermore, it is estimated that the rate of extinction of freshwater organisms could be as high as $4 \%$ per decade (Dudgeon et al., 2006), and knowledge with regard to the conservation status of South African freshwater molluscs is poor (Herbert, 1998). With regard to its conservation status, B. trapezoidea is listed as 'data deficient' in the revised edition of the ICUN Red Data List, but Seddon et al. (2011) are of the opinion that habitat loss and degradation could pose a threat to Burnupia spp. in general. In view of the fact that members of this genus are sensitive to desiccation and are most frequently found in streams and rivers, global warming could have a negative impact on their survival. A significant decline in species diversity and numbers of gastropods due to climatic warming was indeed reported by Mouthon and Daufresne (2006) in an assessment of the Sâone River in France. However, in the extensive on-going biodiversity survey of the two rivers and selected tributaries in the North-West Province mentioned earlier, many specimens of $B$. trapezoidea are still being found at new localities (Kemp et al., 2016), and this species could, therefore, probably be considered for listing as not endangered. In view of its relatively wide distribution, largely sessile, benthic lifestyle, and established ability of molluscs to accumulate various substances, including pollutants, in their soft material and shells, it is recommended that the feasibility to utilise B. trapezoidea as an indicator of river ecosystem health in South Africa should be explored.

\section{ACKNOWLEDGEMENTS}

We are indebted to the Unit for Environmental Science and Management of the Potchefstroom Campus of the North-West University for infrastructure and financial support, Ms M Kemp for the detailed distribution map and Mr Shawn Liebenberg of the Statistical Consultation Service of the Potchefstroom Campus of the North-West University for his assistance in processing the data.

\section{REFERENCES}

APPLETON CC (2002) Mollusca. In: De Moor IJ and Day JA (eds) Guides to the Freshwater Invertebrates of Southern Africa, Arachnida
\& Mollusca, Araneae, Water Mites \& Mollusca. WRC Report No 182/02. Water Research Commission, Pretoria. 42-125.

BROWN DS (1994) Freshwater Snails of Africa and their Medical Importance (Revised $2^{\text {nd }}$ edn). Taylor \& Francis, London. 609 pp.

CARELL B, FORBERG S, GRUNDELIUS E, HENRIKSON L, JOHNELS A, LINDH U, MUTVEL H, OLSSON M, SVÄRDSTRÖM K and WESTERMARK T (1987) Can mussel shells reveal environmental history. Ambio 16 2-10.

COHEN J (1977) Power Analysis for the Behaviour Sciences (Revised edn) Academic Press, Orlando.

CONNOLLY M (1939) A monographic survey of the South African nonmarine Mollusca. Annls. S. Afr. Mus. 33 1-660.

DALLAS HF (2007) The influence of biotope availability on macroinvertebrate assemblages in South African Rivers: implications for aquatic bioassessment. Freshwater Biol. 52 370-380. https://doi. org/10.1111/j.1365-2427.2006.01684.x

DAVIES-COLEMAN HD and PALMER CG (2004) The use of a freshwater mollusc, Burnupia stenochorias (Ancylidae) as an ecotoxicological indicator in whole effluent toxicity testing. Proc. 2004 Water Institute of Southern Africa (WISA) Biennial Conference. 309-315.

DE KOCK KN and WOLMARANS CT (2005a) Distribution and habitats of the Bulinus africanus species group, snail intermediate hosts of Schistosoma haematobium and S. mattheei in South Africa. Water SA 31 117-126.

DE KOCK KN and WOLMARANS CT (2005b) Distribution and habitats of Bulinus depressus and possible role as intermediate host of economically important helminth parasites in South Africa. Water SA 31 491-496.

DE KOCK KN and WOLMARANS CT (2009) Verspreiding van Burnupia capensis (Walker 1912) en Burnupia stenochorias (Melvill \& Ponsonby 1903) (Gastropoda: Ancylidae) in Suid-Afrika. S. Afr. Tydskr. Natuurwet. Teg. 28 220-235. https://doi.org/10.4102/satnt. v28i3.59

DUDGEON D, ARTHINGTON AH, GESSNER MO, KAWABATA Z-I, KNOWLER DJ, LÉVÊQUE C, NAIMAN RJ, PRIEUR-RICHARD A-H, SOTO D, STIASSNY LJ and co-authors (2006) Freshwater biodiversity: Importance, threats, status and conservation challenges. Biol. Rev. 81 163-182. https://doi.org/10.1017/s1464793105006950

GRIFFITHS C, DAY J and PICKER M (2015) Freshwater Life: A Field Guide to the Plants and Animals of Southern Africa. Struik Nature, Cape Town. 368 pp.

HERBERT DG (1998) Molluscan conservation in South Africa: diversity, issues and priorities. J. Conchol., Special Publication 2 61-76.

KEMP M, DE KOCK KN, ZAAYMAN JL and WOLMARANS CT (2016) A comparison of mollusc diversity between the relatively pristine Marico River and the impacted Crocodile River, two major tributaries of the Limpopo River, South Africa. Water SA 42 (2) 253-260. https://doi.org/10.4314/wsa.v42i2.09

KORNIUSHIN AV (2000) Review of the family Sphaeriidae (Mollusca: Bivalvia) of Australia, with the description of four new species. Rec. Aust. Mus. 52 41-102. https://doi.org/10.385 3/j.0067-1975.52.2000.1308

KRAUSS F (1848) Die Südafrikanischen Mollusken. Ein Beitrag zur Kenntniss der Mollusken des Kap- und Natallandes und zur Geographischen Verbreitung derselben mit Beschreibung und Abbildung der neuen Arten. Ebner and Seubert, Stuttgart, 140 pp. https://doi.org/10.5962/bhl.title.13936

LIAW A and WIENER M (2002) Classification and regression by Random Forest. R News 2 18-22.

LYDEARD C, COWIE RH, PONDER WF, BOGAN AE, BOUCHET P, CLARK SA, CUMMINGS TJ, FREST OG, DAI GH, HERSHLER R and co-authors (2004) The global decline of nonmarine mollusks. BioScience 54 321-330. http://dx.doi. org/10.1641/0006-3568(2004)054[0321:TGDONM]2.0.CO;2

MOUTHON J and DAUFRESNE M (2006) Effects of the 2003 heatwave and climatic warming on mollusc communities of the Saône: a large lowland river and two of its main tributaries (France). Global Change Biol. 12 441-449. https://doi.org/10.1111/j.1365-2486.2006.01095.x

OBERHOLZER G and VAN EEDEN JA (1969) Studies on the morphology and histology of Burnupia mooiensis (Walker) 
(Mollusca, Basommatophora, Ancylidae). Wetenskaplike Bydraes van die PU vir CHO, Reeks B: Natuurwetenskappe 7 1-69.

ODUME ON, PALMER CG, ARIMORO FO and MENSAH PK (2015) Influence of selected biotopes on chironimid-based bioassessment of the Swarkops River, Eastern Cape, South Africa. Water SA 41 343-358. https://doi.org/10.4314/wsa.v41i3.06

POURANG N (1996) Heavy metal concentrations in superficial sediments and benthic macroinvertebrates from Anzali wetland, Iran. Hydobiologia 331 53-61. https://doi.org/10.1007/BF00025407
R CORE TEAM (2013) A language and environment for statistical computing. R Foundation for Statistical Computing, Vienna, Austria. URL: https//www. R-project.org/ (Accessed 10 June 2015).

SEDDON M, APPLETON C, VAN DAMME D and GRAF D (2011) Freshwater molluscs of Africa: diversity, distribution and conservation. In: Darwall WRT, Smith KG, Allen DJ, Holland RA, Harrison IJ and Brooks EGE (eds.) The Diversity of Life in African Freshwaters: Under Water, Under Threat. An Analysis of the Status and Distribution of Freshwater Species Throughout Mainland Africa. IUCN, Cambridge. 92-125.

WALKER B (1923) The Ancylidae of South Africa. London. Adlard and Son West Newland Ltd., London. 82 pp. 